\title{
Simple and Rapid Method for Extraction of Good Quality Fungal DNA Directly from Fusarium Wilt Infected Banana and Molecular Characterization of the Pathogen
}

\author{
N. P. Lishma ${ }^{1 *}$ K. Anita Cherian' ${ }^{1}$ and Deepu Mathew ${ }^{2}$ \\ ${ }^{1}$ Department of Plant Pathology, ${ }^{2}$ Department of Plant Biotechnology, College of \\ Horticulture, Kerala Agricultural University, Thrissur, 680 656, India \\ *Corresponding author
}

\section{A B S T R A C T}

Keywords

Foc,DNA isolation,PCR, sequencing, phylogenetic analysis

\section{Article Info}

Accepted:

20 May 2020

Available Online:

10 June 2020
The study was undertaken to isolate the DNA of good quality from the banana wilt pathogen Fusarium oxysporum f. sp. cubense (Foc) directly from infected tissues for molecular studies. In this method, laborious and time-consuming procedures such as isolation of the pathogen and its artificial cultivation are avoided. Moreover, grinding of the fungal mycelium using liquid nitrogen is also not needed as the DNA is directly extracting from infected banana tissues. This is the first attempt to isolate Foc DNA directly from infected tissues. Extraction buffer containing 2 percent CTAB, $0.7 \mathrm{M} \mathrm{NaCl}$, $20 \mathrm{mM}$ EDTA, $50 \mathrm{mM}$ Tris $\mathrm{HCl}$, B-mercaptoethanol and 1 per cent PVP was used for the isolation of fungal DNA from the infected rhizome. The concentration of DNA was 751.6 $\mathrm{ng} / \mu \mathrm{l}$. OD ratio $\lambda_{260} / \lambda_{280}$ obtained was 1.89 which comesin between 1.8 to 2 indicates the purity of DNA isolated. The ITS region of 5.8S rDNA was amplified using the ITS $1 \mathrm{~F}$ and ITS 4R primers. A single band of size approximately $580 \mathrm{bp}$ was obtained as a result of PCR analysis. A tree inferred from phylogenetic analysis using Maximum Likelihood method revealed that sequence was closely related with Foc isolates which is supported by a good bootstrap value of 96 percent.

\section{Introduction}

Banana is an important fruit crop in tropical and subtropical countries. However, its production is constrained by several diseases that affect yield and quality of the fruits. Fusarium wilt, the most destructive disease of banana was first reported from Panama, Tropical America ${ }^{1}$. Since then, the disease was widely spread throughout the world. In India, Fusarium wilt of banana was first informed from West Bengal in 1911. Then it became the most destructive disease in other banana rising states. In Kerala, the southernmost state of Indian peninsula so far it was reported on banana varieties likes Rasthali, Njalipoovan and Kadali.

Causal agent ${ }^{2,3}$ of Fusarium wilt of banana is a soil borne fungus, Fusarium oxysporum $\mathrm{f}$. sp. cubense (E. F. smith) (Foc) ${ }^{4}$. It is a typical vascular disease and the pathogen enters the 
plant through water conducting xylem vessels; thus, causes blockage of water conducting vessels and results in wilted appearance $^{5}$. It is a polycyclic disease; pathogen is capable of causing more than one disease cycle per season ${ }^{6}$.

The disease causes huge economic loss to banana farmers. Hence, the proper diagnosis and timely management of the disease are necessary. Cultural and morphological identification of the disease is difficult because of the great diversity among Fusarium spp. Nowadays, several studies have been conducted for the identification of $F$. oxysporum at the molecular level using PCR based methods ${ }^{7}$.

Isolation of total genomic DNA from Foc infected banana was carried out using CTAB method by several researchers. Extraction buffer consisting of $40 \mathrm{mM}$ EDTA and 100 $\mathrm{mM}$ Tris- $\mathrm{HCl}$ was used $^{8}$ for the isolation of genomic DNA from Foc. Proteins present were removed by the addition of $24: 1$ chloroform: isoamyl alcohol and the nucleic acid was precipitated by treating with ice cold isopropanol. Molecular characterization ofFoc isolates were carried out with the reaction mixture $(25 \mu \mathrm{l})$ consisted of 1X PCR buffer, $2.5 \mathrm{mM} \mathrm{MgCl}_{2}, 0.6 \mathrm{mM}$ of each dNTPs, 0.25 $\mu \mathrm{M}$ of each primer and1.25 U Taq DNA polymerase $^{9}$. Molecular characterization of Fusarium was carried out to identify the isolates at species level through ITS - rDNA sequence analysis universal primers ITS $1 \mathrm{~F}$ and ITS $4 \mathrm{R}^{10}$. Studies have been conducted to observe the relationship pattern of Foc isolates from banana by means of sequencing and phylogenetic tree analysis ${ }^{11}$. Phylogenetic tree analysis done by Maximum Likelihood method with 1000 bootstraps showed the evolutionary relationship among the Foc isolates $^{12}$. Advanced detection and identification methods could provide more rapid, accurate, and reliable diagnoses of plant diseases at their early stages, which in turn makes it possible to reduce the impact of disease outbreaks ${ }^{13}$.

\section{Materials and Methods}

\section{Extraction and gel electrophoresis of fungal genomic DNA}

Genomic DNA of the Fusarium wilt infected rhizome collected from Thrissur district of Kerala was extracted for molecular characterization of the pathogen. The tissue was homogenised in $1 \mathrm{ml}$ of extraction buffer consisting of 2 percent CTAB (cetyl trimethylammonium bromide), $0.7 \mathrm{M} \mathrm{NaCl}$ (sodium chloride), 20mM EDTA (ethylene diamine tetra acetic acid), $50 \mathrm{mM}$ Tris $\mathrm{HCl}, 50$ $\mu \mathrm{l}$ of $\beta$-mercaptoethanol and 1 per cent polyvinylpyrrolidone. This mixture was incubated in a water bath at $65^{\circ} \mathrm{C}$ for 45 minutes.

After incubation, it was treated with equal volume of isoamyl alcohol and centrifuged at $10000 \mathrm{rpm}$ for 10 minutes at $4^{\circ} \mathrm{C}$. The supernatant obtained was mixed with equal volume of ice-cold isopropanol and kept for 2 hours incubation at $-20^{\circ} \mathrm{C}$. Again, centrifuged at $13000 \mathrm{rpm}$ for 10 minutes at $4^{\circ} \mathrm{C}$. After decanting the supernatant, the DNA pellet was rinsed with $200 \mu$ l of each 70 percent and 100 percent ethanol subsequently. The pellet was air dried, dissolved in $50 \mu \mathrm{l}$ of Tris EDTA buffer and stored at $-20^{\circ} \mathrm{C}$ for further use.

Agarose gel electrophoresis was carried out in Tarson electrophoresis unit to check the quality of the genomic DNA. Agarose gel of 0.8 percent was prepared in distilled water and $1 \mathrm{X}$ TAE (Tris-Acetate-EDTA) buffer which provides a source of ions for electric field during electrophoresis. Gel documentation of total DNA obtained was carried out using BIORAD Molecular Imager. 
Polymerase chain reaction using ITS primers

Genomic DNA extracted from the infected tissue was quantified using the instrument NanoDrop spectrophotometer (NanoDrop ND-1000) based on absorbance readings at 260 and $280 \mathrm{~nm}\left(\lambda_{260} / \lambda_{280}\right.$ ratio $)$.

PCR amplification reactions were carried out in $25 \mu 1$ reaction mixture in a Nexus gradient Master cycler. Each reaction mixture consisting of 10X PCR buffer, $25 \mathrm{mM} \mathrm{MgCl}_{2}$, $0.2 \mathrm{mM}$ dNTP, DNA sample, $10 \mathrm{pmol}$ of forward primer and reverse primer, Taq DNA polymerase and distilled water.

The ITS region of rDNA was amplified using the universal primers, ITS 1F (5'-TCC GTA GGT GAA CCT GCG G-3') and ITS 4R (5'TCC TCC GCT TAT TGA TAT GC-3'). PCR amplification profile followed was as follows; initial denaturation at $94^{\circ} \mathrm{C}$ for 10 minutes, 35 cycles of denaturation at $94^{\circ} \mathrm{C}$ for 1 minute, annealing at $54.9^{\circ} \mathrm{C}$ for 1 minute and extension step at $72^{\circ} \mathrm{C}$ for 1 minute, followed by final extension at $72^{\circ} \mathrm{C}$ for 10 minutes.

The PCR products were resolved in 1.5 percent agarose gel stained with ethidium bromide $(10 \mathrm{mg} / \mathrm{ml})$ immersed in $1 \mathrm{X}$ TAE buffer and visualized.

\section{Sequencing and phylogenetic analysis}

The sequencing of the amplified product obtained through PCR using universal primers ITS $1 \mathrm{~F}$ and ITS 4R was done on Sanger platform. BLASTn of the sequence revealed the identity of the pathogen and sequence was submitted to GenBank.

The sequences of Fusarium spp. selected from NCBI along with the sequence of isolated DNA were aligned with ClustalW tool accessible in MEGA-X software by means of Maximum Likelihood construction method with a bootstrap value of 1000 .

\section{Results and Discussion}

\section{Isolation of DNA}

The isolation of good quality DNA of the pathogen is required for molecular works and is important for the proper management of the disease. The method employed here is rapid and inexpensive which avoids the time consuming and difficult process explained in former methods as the isolation of pathogen ${ }^{14}$, its artificial cultivation and grinding with liquid nitrogen ${ }^{15}$.

Extraction buffer used in this protocol was the modifications of earlier reported method for extraction of DNA from Foc culture ${ }^{16}$.In this protocol, 2 per cent CTAB and $20 \mathrm{mM}$ EDTA were added instead of 1 per cent $C T A B$ and $25 \mathrm{mM}$ EDTA used in former method.

In addition to this, $50 \mu 1$ of $\beta$-mercaptoethanol and 1 per cent polyvinylpyrrolidone were also used during the grinding of $1 \mathrm{mg}$ tissue. EDTA inactivates ${ }^{17}$ the endonucleases and $\beta$ mercaptoethanol prevents the phenolic oxidation.

CTAB avoids the polysaccharides contamination whereas, the isopropanol and ethanol allow the actual precipitation of DNA and remove the salts and detergents, making it more stable. The quantity of DNA extracted was measured using a NanoDrop spectrophotometer. The concentration of DNA yield was $751.6 \mathrm{ng} / \mu \mathrm{l}$. OD ratio $\lambda_{260} /$ $\lambda_{280}$ obtained was 1.89 which relies between 1.8 to 2 indicates the DNA is free from protein and RNA impurities ${ }^{18}$. Gel electrophoresis of the isolated DNA was carried out and documented using BIORAD Molecular Imager (Figure.1). 


\section{Amplification of ITS - rDNA region}

A range of temperature from $54.7^{\circ} \mathrm{C}$ to $57.7^{\circ} \mathrm{C}$ was used for the standardization of annealing temperature and the good quality band of amplicons were obtained at $54.9^{\circ} \mathrm{C}$. The isolate was amplified at $580 \mathrm{bp}$ using ITS $1 \mathrm{~F}$ and ITS $4 \mathrm{R}$ primers ${ }^{19}$ andPCR product obtained was compared with $\mathrm{GeNei}^{\mathrm{TM}}$ StepUp $^{\mathrm{TM}} 100$ bp DNA ladder ${ }^{20}$. Figure 2 represents the amplification of PCR product in 1.5 percent agarose gel.

\section{Sequencing and phylogenetic analysis}

The sequencing ${ }^{21}$ of amplicon obtained through PCR was done and compared with top hit accessions available in NCBI database. In silico analysis showed that the isolate exhibited 100 percent similarity with $F$. oxysporum f. sp. cubense accessions infecting banana. The sequence was submitted in NCBI database through BankIt program ${ }^{22}$ and obtained the accession number MN953004.

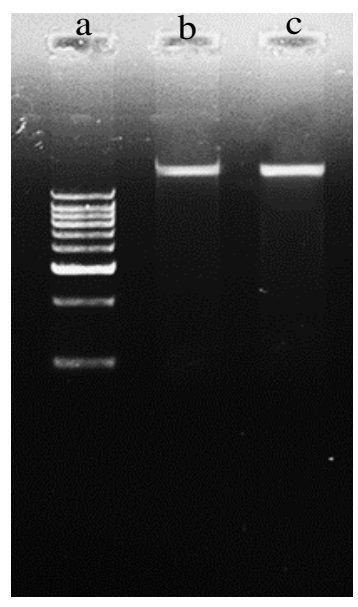

Figure.1 Documentation of DNA isolated. A) $1 \mathrm{~kb}$ molecular marker.

b \& c) replica of Foc DNA isolated

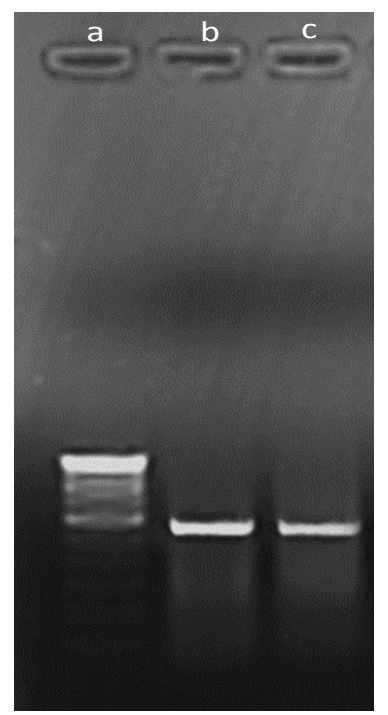

Figure.2 PCR product amplified with ITS 1F and ITS 4R primers

a) $100 \mathrm{bp}$ molecular marker. b \& c) replica of PCR products of Foc isolate 


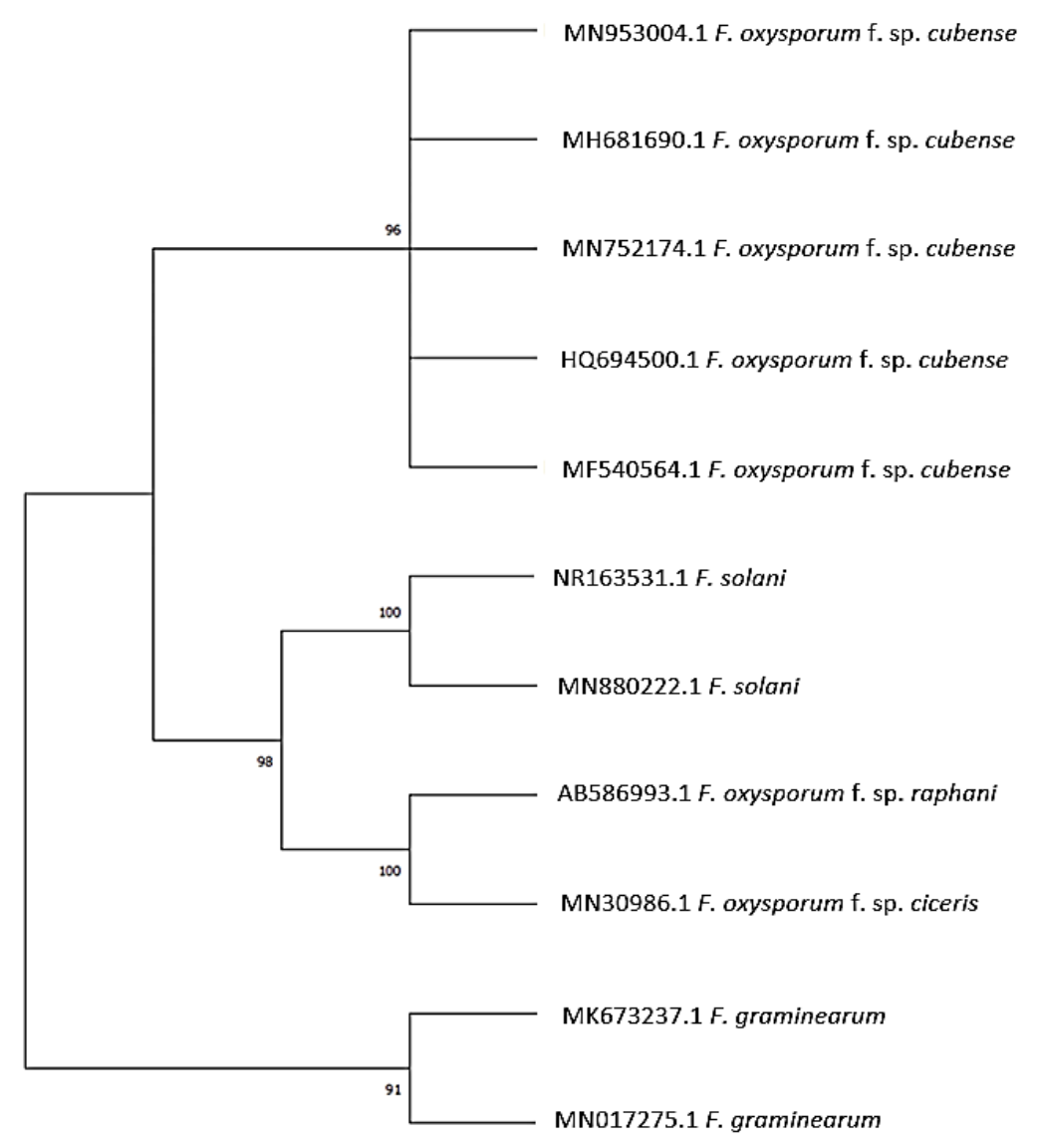

Figure.3 Phylogenetic analysis of Foc isolate MN953004 on the basis of ITS primers, dendrogram generated using MEGA X software with Maximum Likelihood method

The phylogenetic analysis of the isolate MN953004 was done by aligning the sequences of various Fusarium spp. available in NCBI. The phylogenetic tree constructed by Maximum Likelihood method ${ }^{23}$ with a bootstrap value of 1000using MEGA $X$ software ${ }^{24}$ was shown in the Figure3. The sequences were classified into two major clades.

The first clade included all $F$. oxysporum and $F$. solani isolates whereas, second clade consisted of $F$. graminearum isolates. The isolate MN953004 was clustered in the first clade along with four other Foc isolates taken from NCBI. The phylogenetic tree analysis shows that the isolate MN953004 belongs to the Foc group with 96 percent of bootstrap support.

In conclusion, Good quality DNA of Fusarium oxysporum f. sp. Cubense (E. F. Smith) can be isolated using extraction buffer containing 2 percent $\mathrm{CTAB}, 0.7 \mathrm{M} \mathrm{NaCl}, 20$ mM EDTA, $50 \mathrm{mM}$ Tris $\mathrm{HCl}, 50 \mu \mathrm{l}$ of $\beta$ mercaptoethanol and 1 per cent PVP. Foc gives better amplification at an annealing temperature of $54.9^{\circ} \mathrm{C}$ and a band size of approximately 580 bp was obtained. The isolate used for the study was sequenced and In silico analysis displayed 100 percent similarity with Foc accessions. The sequence was deposited in NCBI database and the accession number was obtained as 
MN953004. The phylogenetic tree clearly showed that the isolate MN953004 was closely related with Foc isolates with a good bootstrap value. This method can be used for isolation of high-quality DNA required for molecular research.

\section{Acknowledgement}

Authors are thankful to the Kerala Agricultural University for providing the necessary facilities and fund to carry out the present study.

\section{References}

1. Stover, R. H., Fusarium Wilt (Panama Disease) of Banana and other Musa species. Commonwealth Mycological Institute. Kew. 1962, 117.

2. Snyder, W. C. and Hansen, H. N., The species concept in Fusarium. Am. J. Bot., 27, 1940, 64-67.

3. O’Donnell, K., Gueidan, C., Sink, S., Johnston, P. R., Crous, P. W., Glenn, A., Riley, R., Zitomer, N. C., Colyer, P., Waalwijk, C.andVan der Lee, T., A two-locus DNA sequence database for typing plant and human pathogens within the Fusarium oxysporum species complex. Fungal Genetics Biol., 46, 2009, 936-948.

4. Parham, B. E. V., Annual report of banana disease investigations for the year 1934. Annual Bulletin Division Report for 1934. Department of Agriculture, Fiji, 1935, 41-48.

5. Saravanan, T., Muthusamy, M. and Marimuthu, T., Development of integrated approach to manage the Fusarial wilt of banana. Crop Prot., 22, 2003, 1117-1123.

6. Ploetz, R. C., Management of Fusarium wilt of banana: A review with special reference to tropical race 4. Crop Prot., 73, 2015, 7-15.
7. Prashant, K. M., Roland, T. V. F. and Alastair, C., Development of a PCRbased assay for rapid and reliable identification of pathogenic Fusaria. FEMS Microbiol. Lett.218, 2003, 329332.

8. Bentley, S., Pegg, K. G. and Dale, J. L., Optimization of RAPD- PCR fingerprinting to analyse genetic variation within populations of Fusarium oxysporum f. sp. cubense. J. Phytopathol., 142, 1994, 64-78.

9. Leong, S. K., Latiffah, Z. and Baharuddin, S., Molecular characterization of Fusarium oxysporum f. sp. cubense of banana. Am. J. Appl. Sci.,6, 2009, 1301-1307.

10. Sreeja, S. J., Integrated management of Fusarium wilt and anthracnose of vegetable cowpea (Vigna unguiculata sub sp. sesquipedalis (L) Verdcourt) using new generation fungicides. Ph.D.(Ag) thesis, Kerala Agricultural University, Thrissur, 2014, 182.

11. Thangavelu, R., Kumar, K. M., Devi, P. G. and Mustaffa, M. M., Genetic diversity of Fusarium oxysporum f. sp. cubense isolates (Foc) of India by inter simple sequence repeats (ISSR) analysis. Molecular Biotechnol.,51, 2012, 203-211.

12. Muhammad, A., Hussain, I., Khanzada, K. A., Kumar, L., Ali, M., Yasmin, T. and Hyder, M. Z., Molecular characterization of Fusarium oxysporum f. sp. cubense (Foc) tropical race 4 causing Panama disease in Cavendish banana in Pakistan. Pak. J. Agric. Sci. 54, 2017, 1-8.

13. Lin, Y. H. and Lin, Y. J., Recent developments in the molecular detection of Fusarium oxysporum $f$. sp. cubense. J. Nature Sci.2, 2017.

14. Wu, K.L., Chen, W.Z., Shuai, Y.A.N.G., Ya, W.E.N., Zheng, Y.R., 
Anjago, W.M., Yun, Y.Z. and Wang, Z.H., Isolation and identification of Fusarium oxysporum f. sp. cubense in Fujian Province, China. J.Integr. Agric., 18, 2019, 1905-1913.

15. Zhang, X., Zhang, H., Pu, J., Qi, Y., $\mathrm{Yu}, \mathrm{Q}$., Xie, Y. and Peng, J., Development of a real-time fluorescence loop-mediated isothermal amplification assay for rapid and quantitative detection of Fusarium oxysporum f. sp. cubense tropical race 4 in soil. PloS one, 8,2013.

16. Ingle, A. and Ingle, R., Isolation and Identification of Fusarium oxysporum infecting Musa plants in Maharashtra region and their molecular characterization. Asiat. J. Biotech. Res.4, 2013, 28-34.

17. Rogers, S. O. and Benedich, A. J., Extraction of total cellular DNA from plants, algae and fungi. In: Plant Molecular Biology Manual, (eds. Gelvin, S. B. and Schilperoort, R. A.), Springer, Dordecht, 1994, pp. 183-190.

18. Mishra, P. K., Fox, R. T. and Culham, A., Development of a PCR-based assay for rapid and reliable identification of pathogenic Fusaria. FEMS Microbiol. Lett., 218, 2003, 329-332.

19. Abd-Elsalam, K. A., Aly, I. N., AbdelSatar, M. A., Khalil, M. S. and Verreet, J. A., PCR identification of Fusarium genus based on nuclear ribosomalDNA sequence data. Afr. J.Biotechnol., 2, 2003, 82-85.

20. Ramyakrishna, K. andSudhamani, M., The metal binding potential of a dairy isolate, J. Water Reuse Desal., 7, 2017, 429-441.

21. Fourie, G., Steenkamp, E. T., Gordon, T. R. and Viljoen, A., Evolutionary relationships among the Fusarium oxysporum f. sp. cubense vegetative compatibility groups. Appl. Environ. Microbiol. 75, 2009, 4770-4781.

22. Miao, H., Wang, Y., Liu, J., Jia, C., $\mathrm{Hu}, \mathrm{W} .$, Sun, P., Jin, Z. and Xu, B., Molecular cloning and expression analysis of the MaASR1 gene in banana and functional characterization under salt stress. Electron. J.Biotechnol., 17, 2014, 287-295.

23. Li, P., Zhang, H., Chen, X., Qiu, D. and Guo, L., Molecular characterization of a novel hypovirus from the plant pathogenic fungus Fusarium graminearum. Virol.481, 2015, 151-160.

24. Chinju, E. A., Molecular characterization, host range and integrated management of bhindi yellow vein mosaic disease. M.Sc. (Ag) thesis, Kerala Agricultural University, Thrissur, 2019, 98.

\section{How to cite this article:}

Lishma. N. P., K. Anita Cherian and Deepu Mathew. 2020. Simple and Rapid Method for Extraction of Good Quality Fungal DNA Directly from Fusarium Wilt Infected Banana and Molecular Characterization of the Pathogen. Int.J.Curr.Microbiol.App.Sci. 9(06): 2587-2593. doi: https://doi.org/10.20546/ijcmas.2020.906.315 